\title{
Transfer Pricing Documentation: Globalization and Regional Optimization
}

\author{
Svitlana Y. Korol ${ }^{1, *}$, Olena I. Nykyforuk ${ }^{2}$, Ulyana V. Pelekh ${ }^{3}$, Nataliia S. Barabash ${ }^{4}$, \\ Olha M. Romashko ${ }^{1}$

\begin{abstract}
${ }^{1}$ Department of Accounting and Taxation, Faculty of Finance and Accounting, Kyiv National University of Trade and Economics, Ukraine

${ }^{2}$ Department of Infrastructure Development of SO Institute for Economics and Forecasting, 26 Panasa Myrnogo Street, Ukraine ${ }^{3}$ Department of Accounting and Audit, Economic Faculty, Ivan Franko National University of Lviv, Ukraine ${ }^{4}$ Department of Economics and Business Finance, Faculty of Economics, Management and Psychology, Kyiv National University of Trade and Economics, Ukraine
\end{abstract}

Received October 7, 2021; Revised November 19, 2021; Accepted December 13, 2021

\section{Cite This Paper in the following Citation Styles}

(a): [1] Svitlana Y. Korol, Olena I. Nykyforuk, Ulyana V. Pelekh, Nataliia S. Barabash, Olha M. Romashko, "Transfer Pricing Documentation: Globalization and Regional Optimization," Universal Journal of Accounting and Finance, Vol. 10, No. 1, pp. 219-230, 2022. DOI: 10.13189/ujaf.2022.100123.

(b): Svitlana Y. Korol, Olena I. Nykyforuk, Ulyana V. Pelekh, Nataliia S. Barabash, Olha M. Romashko (2022). Transfer Pricing Documentation: Globalization and Regional Optimization. Universal Journal of Accounting and Finance, 10(1), 219-230. DOI: 10.13189/ujaf.2022.100123.

Copyright $\bigcirc 2022$ by authors, all rights reserved. Authors agree that this article remains permanently open access under the terms of the Creative Commons Attribution License 4.0 International License

\begin{abstract}
The study was conducted in order to assess and analyse the impact of globalization and regional optimization on the activities of economic entities that are required to prepare transfer pricing documentation. The methodological background of the study involved the following methods: generalization, explanation, grouping, induction and deduction, as well as analysis and synthesis, which were used to clarify the main scientific categories of research and substantiate the research results. Methods of schematic and graphical representation were used to visualize analytical data, formulate assumptions and substantiate the obtained results. The main focus of the study is on the analysis of the causes of global economic risks and the role of transfer pricing documentation, whose quality will help mitigate the negative consequences of undesirable events for the global economic system. The study found that not all countries apply the international instrument - Multilateral Convention to Implement Tax Treatment Related Measures to Prevent BEPS (MLI). Many countries that have started to use MLI reporting, have no uniform standardized rules for the preparation of transfer pricing documentation. The legislation only defines the list of information to be submitted by taxpayers, provided that the results of their business activities meet certain criteria. The development of a unified methodology
\end{abstract}

for valuing financial assets for tax purposes and preventing their use in illegal financial transactions are the promising areas for further research.

Keywords Base Erosion, Corporate Income Tax, Developing Countries, Foreign Direct Investment, Inequality, International Taxation, Profit Shifting, Tax Avoidance, Tax Havens

JEL Classifications: F21, F23, H25.

\section{Introduction}

The world economic system is in a deep crisis and, according to preliminary estimates of some researchers, the negative consequences of it are much greater than the economic collapse of 2008-2009. The contraction of the world economy in 2021 is expected to be $4.4 \%$. Further stratification of society by income categories is projected [1]. The negative economic consequences of the COVID-19 pandemic were large-scale job cuts due to plant shutdowns and various restrictions imposed by lock-down. This has particularly affected those who did not have 
savings [2]. At the same time, the situation in major global capital markets has allowed experienced and wealthy investors to make extra profits [3].

The 16th Global Risks Report 2021 was prepared based on the results of annual surveys and presented at the World Economic Forum on January 19, 2021. The focus is on the risks associated with deteriorating living conditions due to environmental pollution, infectious diseases, the development of digital technologies and the weapons of mass destruction proliferation. Much attention is paid to economic risks, which include geopolitical risks, including interstate conflicts and geopolitization, as well as price volatility, commodity shocks and debt crisis (increasing corporate and public debt), which includes up to 10 global risks by degree of impact [4]. According to the authors of the report, corporate and public finances are overloaded with accumulated debts, resulting in mass bankruptcies, deteriorating payment discipline, crises of liquidity and public finances (including sovereign debt). The World Bank estimates that total debt, including corporate and sovereign (public) debt, rose to $318 \%$ of world GDP in 2018 from $292 \%$ in 2008 [5], and reached $360 \%$ of world GDP in 2021 [6].

The main determinants of imbalances in the global economic system, in particular the rapid development of the debt market, include the introduction of new monetary policy instruments, improved debt service, low interest rates and incentives to borrow [7]. At the same time, the corporate debt is growing against the background of declining global foreign direct investment (FDI), especially in developed countries. Economic systems in developing countries remain more attractive for FDI [8].

It should be noted that one of the reasons for an ambiguous situation with corporate debt may be the use of tax instruments by taxpayers for the purpose of transferring profits to jurisdictions with low tax rates. First of all, multinational corporations, which have an extensive network of branches and permanent offices around the globe, resort to this method of optimizing the tax burden. According to expert estimates, large multinational corporations create up to $\$ 30$ billion, or one third of world GDP and about half of world exports, while providing a quarter of the working population with jobs. The area of activity of financial leaders mainly focuses on the development of digital technologies, mining and financial transactions. According to FORBS, the top 10 most powerful corporations in the world include IT companies and financial intermediaries that actively use digital technologies. These are mainly US and Chinese companies [9].

Low corporate income tax rates or the availability of tax benefits and preferences are common in developing jurisdictions and are classified as countries with low-income per capital [10]. Liberal capital tax rules also apply to small island countries that are included in the list of risky jurisdictions. These jurisdictions, also known as tax havens, are included in special lists by many countries around the world, which provide for strict restrictions on the involvement of contractors registered in these countries in the supply chains [11]. The main users of tax havens are multinational corporations [12] and rich people [13].

According to OECD estimates, the total annual loss of tax revenue due to the transfer of income to low-tax regions ranges from $\$ 100$ to $\$ 240$ billion [14]. The State of Tax Justice estimates that in 2020, multinational corporations transferred $\$ 1.38$ trillion to tax havens, which led to a total loss of budgets of countries in which such revenues were received in the amount of $\$ 245$ billion [15]. The countries where the average corporate tax rate is equal to or lower than $10 \%$ incurred most of these losses. For example, 14 jurisdictions, including the United Arab Emirates, Bahrain, Bahamas, Saint Barthelemy, Bermuda, Cayman Islands, and the British Virgin Islands, apply zero corporate income tax rate. And in 15 other jurisdictions, including Barbados (5.5 percent), Uzbekistan (7.5 percent), and Turkmenistan (8 percent) apply a corporate income tax rate that is lower or equal to 10 percent [16]. At the same time, according to the International Monetary Fund, indirect losses due to the transfer of profits by multinational corporations to low-tax jurisdictions are three times higher than direct losses of corporate tax [17].

The aim of the study was formulated on the basis of these assumptions and observations, which is to assess the impact of globalization on the activities of economic entities that are required to prepare transfer pricing documentation in accordance with international tax rules and national tax law. The aim involves several research objectives:

- $\quad$ study the trends in changing the main parameters of corporate income tax and the dynamics of foreign direct investment;

- substantiate the role of the quality of transfer pricing documentation in the context of globalization and regional optimization of the tax burden.

\section{Methodology}

The study focuses on the causes of certain global economic risks, including the taxpayers' use of asymmetries in tax parameters in different jurisdictions, as well as the use of debt instruments to reduce the tax burden in order to optimize the total tax burden on a group of companies formed to achieve a specific purpose.

The methodological background of the study consists of general scientific theoretical methods: generalization, explanation, grouping, which are used to clarify the main scientific categories of research, justification of new conceptual provisions, principles, concepts and categories. The methods of schematic and graphical representation were used to visualize analytical data, formulate 
assumptions and substantiate the obtained results. The research involved general scientific complementary methods of induction and deduction, as well as analysis and synthesis to identify and arrange gaps in international tax rules, systemic and historical approaches to identifying and describing the main trends in taxation, as well as special methods of grouping, systematization, generalization to identify the main parameters of international tax relations that require special attention in terms of eliminating imbalances due to the peculiarities of the current stage of development of the world economic system. The formal-logical method of scientific knowledge was used to identify the factors influencing the activities of transnational corporations on the global economic system, as well as to advance proposals to improve its economic efficiency.

The theoretical and methodological background of the study involved the recommendations of international organizations, the works of leading scholars in the field of finance, securities market, accounting, taxation, legislation and regulations, international financial reporting standards. The study used analytical, statistical and accounting information posted in open sources on the official websites of the UN, OECD, IMF, WBG, EU.

\section{Results}

Almost all financial and industrial giants are active participants in financial markets, issuing bonds, stocks and other debt instruments. At the same time, powerful corporations create networks of branches, subsidiaries and representative offices in almost all countries of the world, buy controlling stakes in promising and investment-attractive companies engaged in other economic activities. Transnational companies actively involve intermediary companies registered in low-tax or non-tax jurisdictions in their supply chains. A simplified scheme for attracting low-tax or non-tax jurisdictions for the purposes of optimizing the tax burden on production and supply chains is illustrated in Figure 1.

The manufacturing company (MC), or rather its authorized persons, register a joint-stock company. The company may carry out various activities, forming a statutory fund in accordance with the provisions of the legislation of the jurisdiction in which such an intermediary company (IC) is established. The IC issues securities acquired by the $\mathrm{MC}$ or its subsidiaries. Of course, it is difficult to find people willing to buy securities at an open auction issued by an unknown newly created company registered in a jurisdiction that is considered risky. However, it turns out that the entire issue is placed efficiently and quickly, and the MC is recognized as an investor. The money is transferred to the IC's accounts, and the MC increases the financial assets in the form of purchased debt obligations of the IC. The IC, in turn, lends to the MC for a pre-determined amount, accruing interest on the loan.

The MC reduces its corporate income tax liabilities at the place of actual activity by the amount of such interest. The IC, in turn, declares such income, however, does not pay taxes, because the income tax rate in the jurisdiction of the place of its registration is 0 , or is much lower than that in the jurisdiction in which the MC is registered. Subsequently, the amount of interest for the use of debt instruments issued by the whole group of companies is consistent with the global amount of profit that the whole group of companies must pay in the relevant jurisdictions in accordance with the provisions of national law.

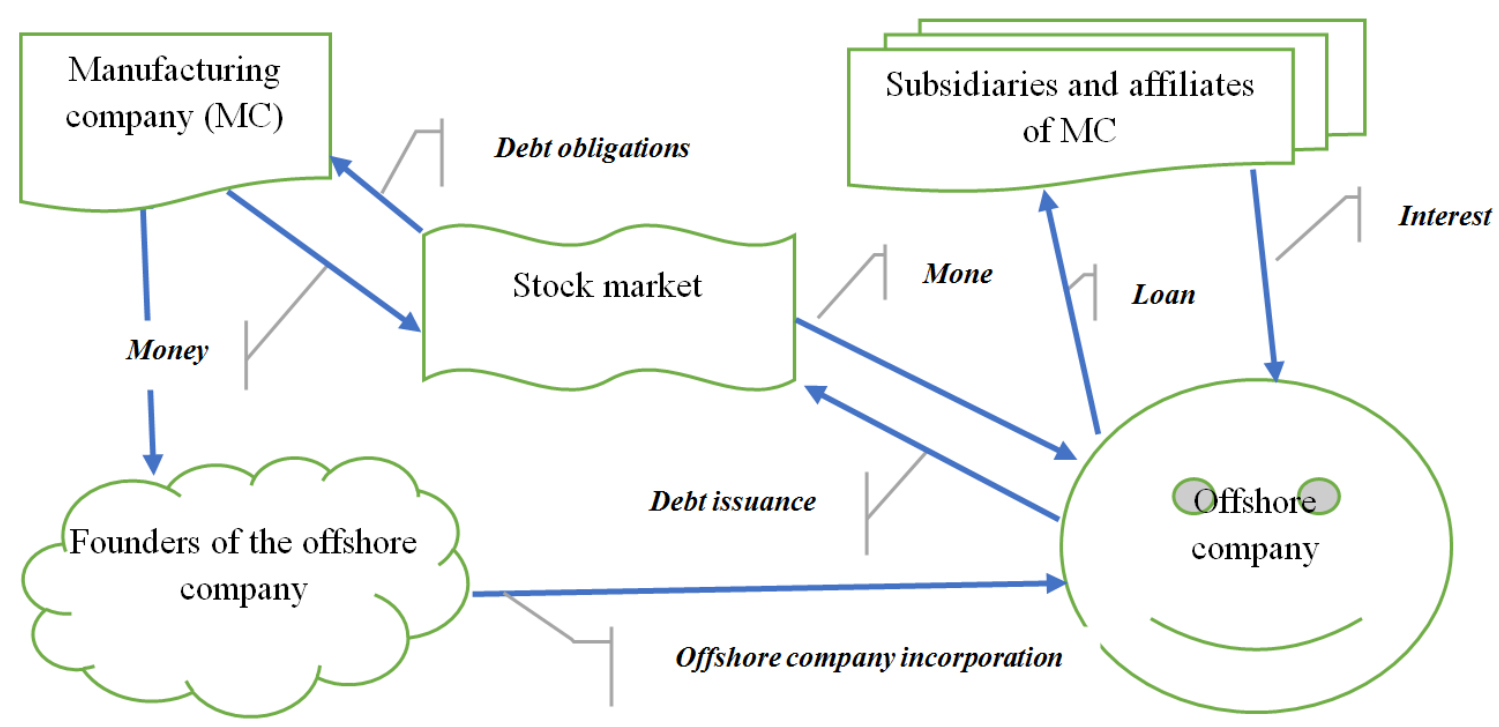

Figure 1. Simplified scheme of using offshore companies for tax optimization purposes 
The scheme presented in Figure 1 is a simplified model of financial activities of companies in terms of optimizing the total tax burden. Such combinations of cash flow distribution channels are much more complex in practice, and carefully disguised in many cases in order to reduce undesirable attention from the tax authorities in terms of a group of companies' compliance with national law. At the same time, the founders of the offshore company and the manufacturing company also receive interest and dividends on debt obligations acquired from the offshore company.

For example, an offshore company may be a subcontractor for the supply of software packages and additional plug-ins. The founders of an offshore company can purchase software from a little-known software development company, which can be specially created for this purpose in some cases. According to the documents, the product will have all the necessary characteristics and will be actively used for the purposes of automation and optimization of any processes in other companies to which business owners are related. Such software (software package) is further sold through a controlled offshore company at a price that can be several times higher than the cost of its acquisition (development). Then Figure 2 will look as follows.

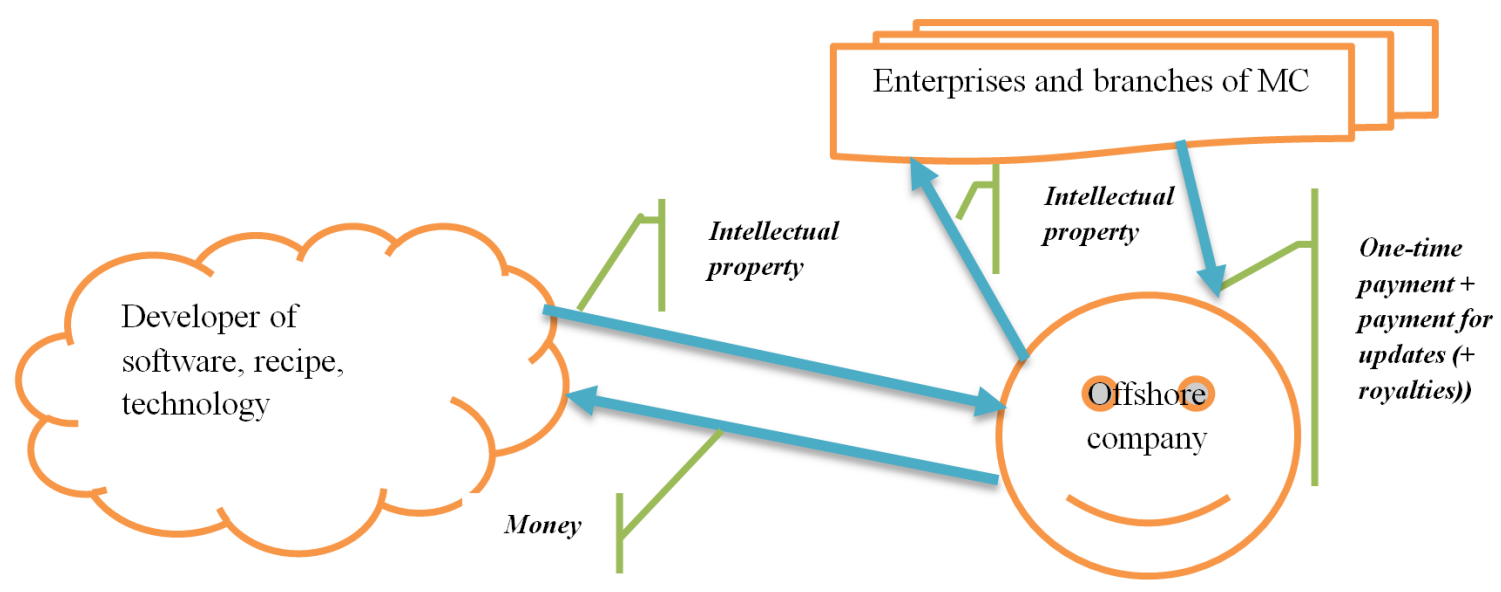

Figure 2. Simplified scheme of using offshore companies for the purposes of tax optimization of the use of intellectual property products.

Software (can also be a recipe or technology, not in the field of digital technology only) will actually be put into operation, and its cost will be depreciated. However, such intangible assets do not provide real benefits in the production process other than tax savings and the creation of additional channels for withdrawing funds to offshore companies in the form of payment for upgrades or royalties.

So, it can be assumed that individual companies deliberately create channels for redistribution of financial flows for the purpose of optimizing tax liabilities in advance. Such channels operate in parallel with the channels in which the real commodity-money exchange takes place. These flows are formed through the issuance of debt instruments and their servicing. The nominal and market value of such instruments, as well as their profitability are established by financial intermediaries in financial markets.

Therefore, the growth of corporate debt should be accompanied by a corresponding reduction in tax revenues and intensification of investment activity in regions that are considered risky for tax purposes. The relevant annual reports of the World Bank and the United Nations show a sharp annual decline in profits of multinational corporations, as well as the rapid growth of total world debt. This observation allows determining the next steps to reduce the main global risks that could lead to another global financial crisis.

One of the ways to reduce the debt burden on the economy may be to improve international tax rules, in particular, on the parameters of taxation of international corporations and the content of transfer pricing documentation in terms of establishing the fair value of financial assets. The main purpose of such improvements should be to ensure a fair distribution of the tax burden on a group of companies between jurisdictions, depending on the amount of value added created by the group of companies, the use of hired labour, as well as tangible and intangible assets.

\section{Analysis}

According to UNCTAD estimates, the profits of multinational corporations in 2020 decreased by $36 \%$ compared to 2019. The reaction of multinational corporations to falling incomes was an increase in corporate debt. About 5000 largest non-financial corporations increased their cash reserves by $25 \%$. Multinational corporations have significantly increased their cash balances under the conditions of declining mergers and acquisitions but the same costs. The dynamics of mergers and acquisitions have been affected by regulatory restrictions adopted by a number of countries to 
protect their companies from acquisitions by foreign investors [18]. It has been proven that raising the capital gains tax rate reduces activity in concluding mergers and acquisitions [19]. In turn, the reduced number and volume of mergers and acquisitions lead to a reduction in total foreign direct investment, the defining characteristic of which is to ensure control over the object of their placement.

The activity of multinational corporations in the financial markets may be one of the reasons for the growth of global corporate debt. After all, the scale of these companies, as well as the extensive and developed infrastructure necessitate the development of appropriate management decisions aimed at ensuring sustainable, socially responsible development of transnational corporations, including the rational use of financial resources.

One of the ways to optimize financial flows generated by the economic activities of multinational corporations is to save on taxes. Optimizing the tax burden within the group of companies that are part of multinational corporations results in the transfer of profits to jurisdictions with low tax rates. In this regard, transnational corporations (MNEs) are criticized by international financial institutions, the OECD in particular, as they violate the principles of vertical and horizontal fairness of the tax system, as well as stimulate tax competition between countries.

The urgency of regional optimization of the total tax burden of multinational corporations has increased due to the intensification of the BEPS (Base Erosion and Profit Shifting) Project, as well as the growing threat of another financial crisis, the risk of which is exacerbated by the continued growth of corporate debt and the COVID-19 pandemic. After all, the use of debt instruments in combination with the involvement of companies registered in jurisdictions with low capital tax rates, including tax havens, still remains a legitimate way to optimize the tax burden.

Given the scale of unfair global tax competition, many countries around the world are taking steps to reduce its negative impact on tax bases. In 2013, the G-20/OECD launched the BEPS Project to improve international tax rules in order to prevent the artificial transfer of tax liabilities, mainly to multinational corporations and wealthy individuals in jurisdictions with low or no income tax. The guiding principle of BEPS is to ensure the taxation of profits in the jurisdiction in which the economic activity is carried out and value added is created [20]. Transfer pricing rules are considered to be the main tool to ensure compliance with the guiding principle.

Transfer pricing rules aim to ensure that the tax liabilities of subsidiaries in the countries in which they operate are not distorted by the fact that they are interconnected. After all, the relatively liberal rules of income taxation provide a competitive advantage of the jurisdiction in terms of placement of foreign direct investment. In addition, multinational corporations are actively using a variety of debt instruments to transfer profits to the jurisdictions which apply more liberal corporate income tax rules. International groups of companies are created for this purpose, some members of which are created for the purpose of optimizing the tax burden on the whole group. In accordance with international rules, international group is a group of two or more companies that are related to each other in terms of control and ownership in compliance with the provisions of International Financial Reporting Standards (IFRS), IFRS 24 in particular [21].

The BEPS Project, to which 140 countries have already joined as of 2021, identifies 15 problem areas (steps), including four "minimum standards" for combating tax evasion strategies, which are based on incompleteness and gaps in tax rules, as well as asymmetry of information held by tax authorities in different jurisdictions [22]. The OECD has developed an innovative multilateral instrument (MLI) as part of the BEPS Project to administer Double Tax Agreements (DTAs), and implemented an Inclusive Framework (IF) to commit to a consistent implementation of the BEPS Project.

The MLI (Multilateral Convention to Implement Tax Treatment Related Measures to Prevent BEPS) is designed to protect the tax bases of countries participating in the BEPS Project from tax evasion strategies used by multinational corporations to prevent the transfer of income for tax purposes to jurisdictions with no or low corporate income tax [14]. As of August 11, 2021, the Convention has been signed by 95 countries.

The MLI minimum standard provides for the introduction of unified taxation of income from the sale of shares, the value of which is derived mainly from real estate, as well as combating the abuse of double taxation agreements in terms of tax evasion by permanent representative offices, including through artificial avoidance of the status of a permanent representative office in particular, agency arrangements and contract distribution. The MLI provisions enter into force for a specific double taxation agreement only if both treaty jurisdictions include such a provision in their Protocols [23].

In pursuance of paragraph 13 of the BEPS Project, the OECD has developed transfer pricing documentation standards [24]. In particular, all large multinationals (MNEs) are required to prepare a country-by-country (CbCR) report with aggregate data on the global distribution of income, profits, taxes paid and economic activity between the tax jurisdictions in which it operates. The CbCR report is submitted to the tax authorities in a standardized electronic format for the exchange of $\mathrm{CbCR}$ reports between jurisdictions - the CbCR XML Schema $[25,26]$. Updated requirements for the content of all types of transfer pricing documentation are defined in the UN Transfer Pricing Guidelines [27]. 
Transfer pricing rules, which are already in place in many countries around the world, are being implemented to prevent business distortions for tax purposes between businesses, when they are related parties, by identifying discrepancies between controlled and uncontrolled transactions. By 2021, some 6,000 groups of multinational companies (MNEs) headquartered in 38 jurisdictions and operating in more than 100 jurisdictions around the world are already reporting under the $\mathrm{CbCR}$ standard, providing tax authorities with aggregated information on global tax and economic activities [28].

The European Union is working to improve the rules of international taxation. In particular, in order to minimize tax fraud or tax evasion, such as illegal non-payment or underpayment of taxes, the use of legal means to minimize tax liabilities, as well as concealment of the origin of illegally gained money, the EU annually updates the list of non-member countries abusing tax practices, thus destroying the corporate income tax base of EU member states [29]. The State of Tax Justice ranking identifies 70 countries that are recognized as tax havens. The leaders of the ranking are British Virgin Island, Cayman Island, Bermuda, which have no income tax. The top ten also include the Netherlands, Switzerland and Luxembourg [30]. The legislation of Ukraine contains a list of 85 countries, transactions with counterparties registered in those jurisdictions are considered controlled [31,32].

Income tax remains an important source of budget revenue, especially for low-income countries [33], the fiscal importance of which is gradually increasing. According to OECD estimates, the share of corporate income tax in total tax revenues in the world over the past 20 years has increased by 3 percentage points, from $12.3 \%$ in 2000 to $15.3 \%$ in 2020 , and in GDP - by $0.5 \%$, from 2.7 to $3.2 \%$, respectively [28].

On average, corporate income tax accounts for a larger share of total tax revenues in Africa (19.2\%), Latin America and the Caribbean (15.6\%) than in developed countries, including OECD countries (10\%) [20]. There is a steady trend towards lower corporate income tax rates in most countries. The average combined corporate income tax rate for all jurisdictions covered fell from $28.3 \%$ in 2000 to $20.0 \%$ in 2021 [20], [34]. That is, there is a global trend towards equalization and unification of the main parameters of capital taxation, which is the result of globalization, the development of corporate finance, as well as the efforts of international organizations, the OECD in particular. The dynamics of changes in the average corporate income tax rate in some regions of the world is illustrated in Figure 3.

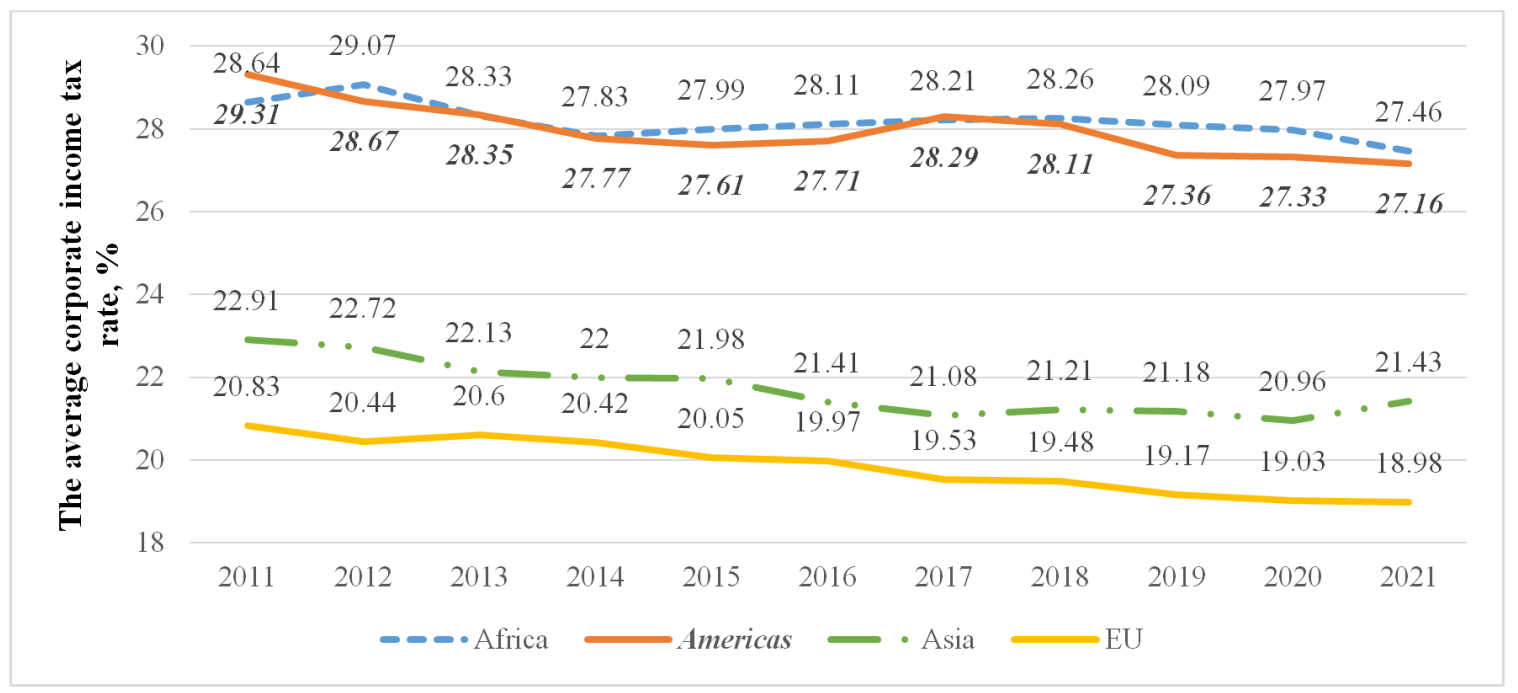

Source: $[35,36]$.

Figure 3. Dynamics of change in the average corporate income tax rate in different regions of the world 
Experts estimate that governments around the world lose about $\$ 0.5$ trillion in tax revenue each year due to tax abuse. At the same time, almost two thirds of this amount fall on transnational corporations, which transfer their profits to jurisdictions with low tax rates. The remaining budget losses are generated by wealthy individuals who conceal undeclared income in offshore countries [15].

The issue of tax competition between jurisdictions for tax bases, including the attraction of profits from other jurisdictions, has long been discussed in the theoretical literature. Some authors, such as [37], note that jurisdictions are lowering income tax rates, thus increasing their attractiveness for foreign direct investment in order to stimulate economic growth.

Foreign direct investment (FDI) is one of the important indicators to describe the attractiveness of a particular jurisdiction, especially for multinational corporations. In general, direct investment provides investor control over the business operations of the recipient company. Investments are aimed at achieving a certain goal, including through the development of physical capital (infrastructure and equipment), human capital (education, professional mobility), technology, as well as financial assets (stocks, bonds).

FDI income consists of a foreign investor's share in the income of its affiliates and net interest on intra-company debt. The change in income generated by dividends and reinvested earnings reflects changes in return on investment. [38] argues that the greater the share of foreign direct investment coming from tax havens, the lower the reported rate of return on these investments declared by companies.

Global flows of foreign direct investment (FDI) in 2020 fell to $\$ 998.8$ billion, or $35 \%$ less than in 2019 . Foreign direct investment is considered to be more sensitive to regulatory influence than portfolio investment. The main cause of such trends is the COVID-19 pandemic, because in order to curb the spread of the COVID-19 pandemic, many countries have taken tough measures to restrict the physical contact of their citizens, including restrictions on movement, closures (schools, institutes, entertainment), transfer of staff to teleworking [39].

Restrictions on the mobility of factors of production have led to a slowdown in the global economic system, the effects of which were preliminary assessed in the works on aggregate consumption [40], on value chains, labour supply and employment [41].

In 2020, global FDI flows fell to $\$ 1$ trillion against $\$ 1.5$ trillion in 2019 [18]. The dynamics of foreign direct investment by region is presented in Table 1 .

Foreign direct investment (FDI inflows) in developed economies is on average equal to the volume of foreign direct investment made by residents of such jurisdictions (FDI outflows). And investment flows (inflows FDI) to developing countries, on average, are almost twice as high as direct investments (outflows FDI) coming from these jurisdictions $[18,42]$.

Table 1. Dynamics of foreign direct investment by regions, $\$$ million

\begin{tabular}{|c|c|c|c|c|c|c|c|c|}
\hline Region & FDI flows & 2014 & 2015 & 2016 & 2017 & 2018 & 2019 & 2020 \\
\hline \multirow{4}{*}{ World } & Inflows & $1,403,865$ & $2,032,298$ & $2,065,238$ & $1,647,312$ & $1,436,732$ & $1,530,228$ & 998,891 \\
\cline { 2 - 9 } & Outflows & $1,366,900$ & $1,698,209$ & $1,616,138$ & $1,604,697$ & 870,715 & $1,220,432$ & 739,872 \\
\cline { 2 - 9 } & in/out & $102.7 \%$ & $119.7 \%$ & $127.8 \%$ & $102.7 \%$ & $165.0 \%$ & $125.4 \%$ & $135.0 \%$ \\
\hline \multirow{5}{*}{ Developed economies } & Inflows & 669,561 & $1,267,808$ & $1,344,533$ & 894,321 & 707,649 & 748,999 & 312,170 \\
\cline { 2 - 9 } & Outflows & 848,356 & $1,262,783$ & $1,173,389$ & $1,087,409$ & 430,584 & 780,489 & 347,162 \\
\cline { 2 - 9 } & in/out & $78.9 \%$ & $100.4 \%$ & $114.6 \%$ & $82.2 \%$ & $164.3 \%$ & $96.0 \%$ & $89.9 \%$ \\
\hline \multirow{5}{*}{ Europe } & Inflows & 329,804 & 712,907 & 766,384 & 502,644 & 344,267 & 362,644 & 72,537 \\
\cline { 2 - 9 } & Outflows & 300,926 & 793,247 & 646,326 & 504,686 & 410,207 & 363,738 & 73,741 \\
\cline { 2 - 9 } & in/out & $109.6 \%$ & $89.9 \%$ & $118.6 \%$ & $99.6 \%$ & $83.9 \%$ & $99.7 \%$ & $98.4 \%$ \\
\hline \multirow{5}{*}{ Developing economies } & Inflows & 677,340 & 730,434 & 653,885 & 702,495 & 692,480 & 729,985 & 682,562 \\
\cline { 2 - 9 } & Outflows & 446,188 & 403,323 & 417,562 & 478,816 & 402,530 & 416,620 & 387,069 \\
\cline { 2 - 9 } & in/out & $151.8 \%$ & $181.1 \%$ & $156.6 \%$ & $146.7 \%$ & $172.0 \%$ & $175.2 \%$ & $176.3 \%$ \\
\hline \multirow{5}{*}{ Transition economies } & Inflows & 56,963 & 34,056 & 66,819 & 50,496 & 36,604 & 57,844 & 24,160 \\
\cline { 2 - 9 } & Outflows & 72,356 & 32,103 & 25,187 & 38,472 & 37,601 & 23,322 & 5,641 \\
\cline { 2 - 9 } & in/out & $78.7 \%$ & $106.1 \%$ & $265.3 \%$ & $131.3 \%$ & $97.3 \%$ & $248.0 \%$ & $428.3 \%$ \\
\hline
\end{tabular}

Source: [18]. 
It should be noted that the decline in profits of multinational corporations in the context of the COVID-19 pandemic may be due in part to the expansion of the BEPS plan, which provides for the unification of double taxation agreements under the MLI Convention, improved information exchange between tax authorities in different jurisdictions. economic and other restrictions for business entities that work with counterparties that are registered in low-tax jurisdictions or have a specific form of business organization, which is classified as risky by international tax rules.

That is, in connection with certain complications in terms of reducing the attractiveness of FDI activities, large taxpayers develop other ways to generate additional income by optimizing supply chains and their financial security, including the use of debt instruments. At the same time, given that not all countries in the world have joined the BEPS Project, taxpayers still have the opportunity to regionally optimize their tax liabilities by involving companies, that are registered in low-tax jurisdictions or have a specific legal status, in production and marketing combinations.

The COVID-19 pandemic accelerates the digitalization of the economy and affects the supply of labour and capital in terms of economic activities and geography. There is a global trend of increasing the importance of e-commerce and related services (cloud technologies for storage and exchange of information, the development of artificial intelligence), there are more remote jobs. Cloud services created by digital giants, such as Amazon, Google Inc., Microsoft Corp, Oracle and Salesforce, allow organizing work in many types economic activities, construction in particular, without being tied to a specific office and/or working hours [43]. As a result, there is a global trend of increasing the share of investment in intangible assets in total investment flows.

Investments in intangible assets contribute to improving the company's economic efficiency, including by increasing labour productivity and return on assets. According to expert estimates, a $10 \%$ increase in investment in intangible assets leads to an increase in labour productivity by $4-4.5 \%$ [44, 45]. However, investments in tangible assets involve the use of high-quality human capital, the cost of which is one of the main factors shaping their value. At the same time, investments in tangible assets are less sensitive to changes in the monetary policy of the jurisdiction, that is the market price of shares of enterprises with a relatively larger share of intangible assets in the capital structure is less volatile as a result of monetary shocks. This is facilitated by higher depreciation rates and relatively lower (in terms of volume) costs for their adaptation to changes in financial markets and the reaction of regulators [46].

Intangible assets are formed through the acquisition of the right to commercial designations, industrial property, copyright and related rights, patents, licenses, concessions, etc., as well as software and databases. According to the McKinsey Global Institute, investment in intangible assets is up to 29 percent in the structure of investments in the United States and the European Union.

In the context of the COVID-19 pandemic, against the background of a sharp decline in global investment flows, there is an acceleration in the growth of the share of investment in intangible assets [47]. For example, in Ukraine, capital investments in intangible assets in 2020 amounted to UAH 25 milliard, or $4.9 \%$ of total capital investments (UAH 420 milliard), of which $55 \%$ went to software and $30 \%$ to patents, licenses etc. [48]. In 2020, compared to 2019, investments in tangible assets in Ukraine decreased by almost 20\%, from UAH 601 milliard in 2019 to UAH 483 milliard in 2020. Instead, investments in intangible assets increased by $6 \%$, from UAH 23.4 milliard in 2019 to UAH 25 milliard in 2020.

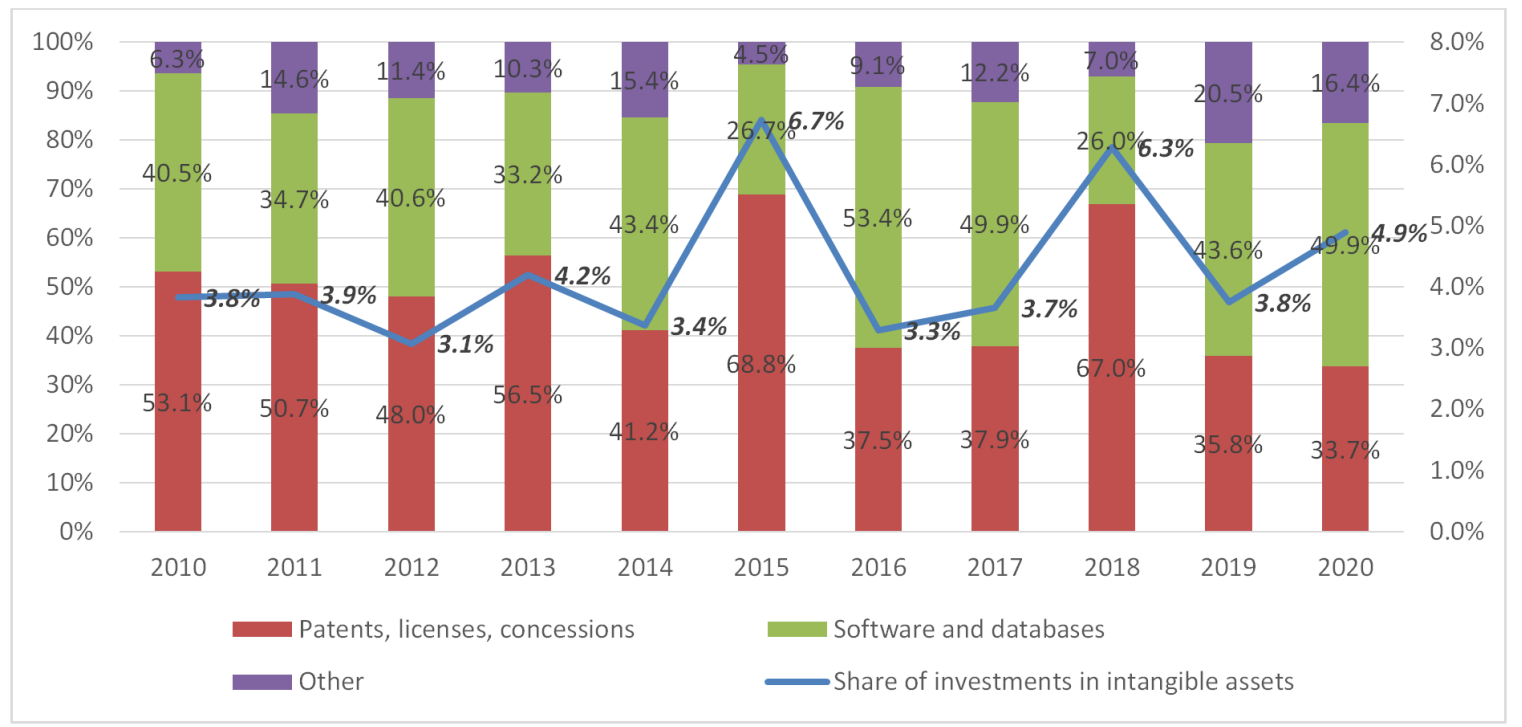

Source: [48]

Figure 4. Dynamics of changes in the structure of investments in intangible assets in Ukraine for 2010-2020 and their share in total capital investments 
The statistics presented in Figure 4 do not allow identifying established trends in Ukraine regarding the impact of changes in the volume and structure of investments in intangible assets on the dynamics of economic development and expanded revival. Besides, the share of capital investments in intangible assets in Ukraine is several times less than in developed countries. Besides, it can be stated that since the beginning of the COVID-19 pandemic, the share of investment in intangible assets in Ukraine in total investment has almost halved, while it shows a rapid growth in 2020 due to increased investment in software and creation of databases, which corresponds to the global trend of development in this area.

The tax legislation in the development of the BEPS Project is being improved in two main areas, which include determining the rights of jurisdictions to tax income in the context of digitalization of the economy (Pillar 1) and the introduction of guarantees for a minimum tax of $15 \%$, which multinational corporations must pay (Pillar 2) [49]. These fundamental directions of international tax development have been agreed within the OECD/G20 Base Erosion and Profit Shifting Project consultations and as of November 4, 2021 have been adopted in 137 countries, which generate up to $90 \%$ of world GDP [50].

With the development of digital technologies and, on this basis, logistics services, multinational corporations no longer need to open offices to sell products in certain jurisdictions. Therefore, as part of the latest BEPS 2.0 innovations, income taxation is being introduced in jurisdictions where goods (services) are sold. From now on, the share of corporate profits will be taxed in the jurisdictions in which their products are consumed in case of exceeding the fixed level of profitability - $10 \%$ (pre-tax profit).

\section{Discussions}

The main difficulties in building a fair global tax system are caused by the fact that all countries consider it appropriate to join the MLI. Moreover, there are some difficulties in the process of tax administration of a group of companies, especially transnational ones, even between the member states of the Convention. After all, in the absence of the double taxation agreement between the countries, which is confirmed by special protocols, the mechanism of the Convention does not apply to the relationship between the tax authorities and counterparties of these jurisdictions. These issues are often resolved in court, and, in most cases, in favour of taxpayers.

To ensure the fairness of the redistribution of the excess profits of individual economic agents, the transfer pricing documentation should provide an accurate transaction price, which can be compared with other similar transactions for compliance with the arm's length principle. The documentation should contain the information necessary for the tax authorities to assess the risks and the taxpayer's position in determining the price of the controlled transaction. Carefully prepared documentation reduces the likelihood of disputes between taxpayers and tax authorities. These considerations form the basis of many recommendations from UN, OCED and other international transfer pricing organizations [27].

The theory refers to the use of international aggressive tax planning schemes, which includes tax evasion taking into account the peculiarities of the tax system in some jurisdictions, to the problem of illegal financial flows [51]. As a result, according to various estimates, multinational corporations (MNEs) annually transfer from $\$ 600$ billion to $\$ 1.1$ trillion of revenues to tax havens $[37,52]$ which is 0.7 to 1.3 percent of world GDP. These issues, including tax competition between jurisdictions for foreign direct investment, as well as related issues of regional optimization of the tax burden using debt instruments, have recently been actively discussed in the scientific literature $[53,54]$. Their solution provides for the consistent implementation of OECD recommendations, including in relation to financial agreements [55].

Similar scientific findings were obtained by [56], which show that multinational corporations (MNEs) are active in cross-border intra-firm transactions, manipulating domestic transfer prices to reduce tax liabilities. Multinational corporations transfer profits to low-tax jurisdictions for this purpose.

Transfer prices are the subject of close attention and disputes between tax authorities and taxpayers in the context of globalization, as well as the heterogeneity of the tax field in terms of jurisdictions and regions. Tax competition between jurisdictions, which is related to their desire to attract foreign direct investment, is used by many taxpayers to regionally optimize the tax burden within international groups of companies. The interaction of tax competition and the transfer of profits by multinational corporations is revealed in [57]. It is noted in the works [36, 56] that the competition of jurisdictions for foreign direct investment is carried out by reducing corporate income tax rates, varying the parameters of taxation of royalties, interest and dividends. The features of the use of the tax system in different jurisdictions for the purposes of regional optimization of the tax burden are covered in $[36$, $58]$.

At the same time, multinational corporations continue to take advantage of the heterogeneity of the global corporate income tax field across jurisdictions, including the use of debt instruments. It should be noted that this method of aggressive tax planning can be used not only by industrial and financial giants. The issue of the investor's reaction to the regulator's actions to prevent low or hidden capitalization in a particular jurisdiction, including by abandoning the scheme of financing at its own expense and replacing it with financing from foreign borrowings is considered [59]. The results of this study confirm the 
possibility of using interest and dividends for the purposes of optimizing the tax burden on a group of companies. After all, according to the rules of tax accounting in many countries, such payments allow taxpayers to reduce pre-tax profits.

The study [51] proves the use of intangible assets for the purpose of building income channels in jurisdictions with more favourable tax regimes. These findings indirectly confirm the statistics on the rapid growth of investment in intangible assets, especially software and databases against the background of a sharp decline in foreign direct investment in tangible assets and a decrease in mergers and acquisitions. This study found that such a trend exists in Ukraine. That is, the digitalization of the economy, which is accelerating as a result of scientific and technological progress, the gradual increase in the general background of computer awareness, as well as the COVID-19 pandemic, in addition to positive effects, including the creation of remote jobs, determines the erosion of the tax base due to the creation and sale of intangible assets for the purposes of optimizing the tax burden.

The trend towards the gradual alignment of the main parameters of corporate income taxation identified in [33] is confirmed by the results of this study. The reasons for such trends identified in this study include the fact that the countries that have acceded to the MLI Convention in the process of implementing its standards to national legislation adopt a standardized OECD corporate income tax mechanism. Besides, blacklisted countries are taking steps to improve their reputation to avoid possible sanctions. Finally, the alignment of capital taxation parameters is under the influence of globalization, the characteristic feature of which is the unification of approaches to the assessment and use of certain phenomena, events, processes, including taxation.

\section{Conclusions}

With the contraction of the world economic system and rising unemployment, there is an increase in the value of assets of wealthy people and corporations. This is explained by unequal opportunities for the development and use of digital technologies, the development of ways of earning with the use of financial and intangible assets, including the use of the latter for the purposes of aggressive tax planning.

The principles of horizontal and vertical fairness must be taken into account in the process of reforming the rules of international taxation, that is tax revenues must go to the budget of the jurisdiction in which the profit is generated. Gross profits identified at the global level should be distributed among the jurisdictions in which they are received, in proportion to and depending on labour and other investments. However, in jurisdictions where the pandemic itself is actively exacerbating inequality, taxation should be focused on mitigating its negative impact.

Uniform taxation rules should be based on an algorithm by which a corporation or group of companies initially declares aggregate pre-tax profit, which is then distributed among all branches, subsidiaries and representative offices in accordance with the economic benefits acquired by the corporation in a particular jurisdiction and the labour, assets used, etc.

The main tool for achieving the outlined directions of improvement of the international rules of corporate income taxation should be the standardized global transfer pricing documentation, where the issues of using financial and intangible assets will be declared and covered. Global transfer pricing documentation at all levels should include detailed information on the participants in transactions with financial and intangible assets, as well as provide an opportunity to analyze such transactions for their compliance with the arm's length principle.

Statement on a Two-Pillar Solution to Address the Tax Challenges Arising from the Digitalisation of the Economy adopted within the recent G20 Framework Agreement on BEPS 2.0 bring the tax systems of different countries closer in terms of preventing aggressive tax planning, and promote horizontal and vertical alignment of tax parameters. Their main drawback is the expected significant complication and increase in the cost of tax administration, which may lead to increased tensions in this area, among other things, because of the increasing number of lawsuits.

The promising areas of further research can be scientific justification for solving the problem of asymmetry of the main parameters of corporate income taxation, as well as information exchange of tax authorities in different jurisdictions. It is also advisable to pay attention to the development of a unified methodology for valuing financial and intangibles assets for tax purposes and preventing their use in illegal financial transactions.

\section{REFERENCES}

[1] International Monetary Fund. World Economic Outlook, October 2020: A Long and Difficult Ascent. 2020. Online available from https://www.imf.org/en/Publications/WEO/ Issues/2020/09/30/world-economic-outlookoctober-

[2] International Labour Organization. Monitor: COVID-19 and the world of work. 6th edition. ILO, Geneva, 2020.

[3] Bloomberg. Markets - Stocks, Overview. 2020. Online available from https://www.bloomberg.com/markets/stocks

[4] World Economic Forum. The Global Risks Report 2021. 2021. Online available from http://wef.ch/risks2021

[5] F. Abraham, J. J. Cortina, S. L. Schmukler. Growth of Global Corporate Debt: Main Facts and Policy Challenges. 
World Bank Group, Washington, D. C., 2020.

[6] E. Tiftik, K. Mahmood. Chipping Away at the Mountain? 2021. Online available from https://www.iif.com/Portals/0/Files/content/Global\%20De bt\%20Monitor_May2021_vf.pdf

[7] International Monetary Fund. World Economic Outlook: Managing Divergent Recoveries. IMF, Washington, D.C., 2021.

[8] United Nations Conference on Trade and Development. Global Investment Trends Monitor. UNCTAD, Geneva, 2020.

[9] A. Murphy, E. Haverstock, A. Gara, C. Helman, N. Vardi. GLOBAL 2000. How The World's Biggest Public Companies Endured The Pandemic. 2021, May 13. Online available from https://www.forbes.com/lists/global2000/\#30 $1325 \mathrm{~b} 95 \mathrm{ac} 0$

[10] World Bank Group. World Bank Country and Lending Groups: Country Classification. 2020.Onlne available from https://datahelpdesk.worldbank.org/knowledgebase/articles/ 906519-world-bank-country-and-lending-groups

[11] D. Dominguez, O. Pantoja, P. Pico, V. Mateos, M. del Mar Alonso-Almeida, M. González. Panama papers' offshoring network behavior. Heliyon, Vol. 6, No. 6, e04293, 2020.

[12] J. O'Donovan, H. F. Wagner, S. Zeume. The value of offshore secrets: evidence from the Panama papers. The Review of Financial Studies, Vol. 32, 4117-4155, 2019.

[13]L. A. B. Ouali. Effects of signalling tax evasion on redistribution and voting preferences: Evidence from the Panama Papers. PLoS ONE, Vol. 15, No. 3, e0229394, 2020.

[14] Organization for Economic Cooperation and Development. Multilateral Instrument - Information Brochure. OECD, Paris, 2020.

[15] Tax Justice Network. The State of Tax Justice 2020: Tax Justice in the Time of COVID-19. TJN, Bristol, 2020.

[16]E. Asen. Corporate Tax Rates around the World. 2020. Online available from https://taxfoundation.org/publications /corporate-tax-rates-around-the-world/

[17] J. Garcia-Bernardo, P. Jansky, T. Tørsløv. Multinational Corporations and Tax Havens: Evidence from Country-by-Country Reporting. Institute of Economic Studies, Prague, 2019.

[18] United Nations Conference on Trade and Development. World Investment Report 2021: Investing in Sustainable Recovery. UNCTAD, Geneva, 2021.

[19] M. Todtenhaupt, J. Voget, L. P. Feld, M. Ruf, U. Schreiber. Taxing away M\&A: Capital gains taxation and acquisition activity. European Economic Review, Vol. 128, 103505, 2020.

[20] Organization for Economic Cooperation and Development. International Collaboration to End Tax Avoidance. OECD, Paris, 2021.

[21] International Accounting Standards Committee. IAS 24 Related Party Disclosures. 2001.Online available from https://www.ifrs.org/issued-standards/list-of-standards/ias-2 4-related-party-disclosures/

[22] International Monetary Fund, Organization for Economic Cooperation and Development, United Nations, World Bank Group. The Platform for Collaboration on Tax OECD, Paris, 2016.

[23] Organization for Economic Cooperation and Development. Explanatory Statement to the Multilateral Convention to Implement Tax Treaty Related Measures to Prevent Base Erosion and Profit Shifting. OECD. Paris, 2016.

[24] Organization for Economic Cooperation and Development. Transfer Pricing Documentation and Country-by-Country Reporting, Action 13 - 2015 Final. OECD, Paris, 2015.

[25] O rganization for Economic Cooperation and Development. Action 13 Country-by-Country Reporting, 2014. Online available from https://www.oecd.org/tax/beps/beps-actions/ action $13 /$

[26] Organization for Economic Cooperation and Development. Country-by-Country Reporting: Handbook on Effective Tax Risk Assessment. OECD, Paris, 2017.

[27] United Nations. Practical Manual on Transfer Pricing for Developing Countries 2021. 2021. Online available from https://www.un.org/development/desa/financing/sites/www. un.org.development.desa.financing/files/2021-04/TP_2021_ final_web $\% 20 \% 281 \% 29 . p d f$

[28] Organization for Economic Cooperation and Development. Corporate Tax Statistics, 3rd edition. OECD, Paris, 2021.

[29] Council of the European Union. EU list of Non-Cooperative Jurisdictions for Tax Purposes. 2021. Online available from https://www.consilium.europa.eu/en/policies/eu-list-of-noncooperative-jurisdictions/

[30] Tax Justice Network. Corporate Tax Haven Index - 2021 Results. TJN, Bristol, 2021.

[31] Cabinet of Ministers of Ukraine. Resolution of the Cabinet of Ministers of Ukraine № 1045 On Approval of the List of States (Territories) that Meet the Criteria Established by Subparagraph 39.2.1.2 of Subparagraph 39.2.1 of Paragraph 39.2 of Article 39 of the Tax Code of Ukraine, and Recognition of The Order of the Cabinet of Ministers of Ukraine of September 16, 2015 № 977 as Invalid. 2017. Online available from https://zakon.rada.gov.ua/laws/show/ 1045-2017-\%D0\%BF\#Text

[32] Cabinet of Ministers of Ukraine. Resolution of the Cabinet of Ministers of Ukraine № 480 On Approval of the List of Organizational and Legal Forms of Non-Residents Who Do Not Pay Income Tax (Corporate Tax), Including Tax on Income Received Outside the State of registration of such Non-Residents, and / or non-tax Residents of the State in Which They Are Registered as Legal Persons. 2017. Online available from https://zakon.rada.gov.ua/laws/show/480-2017-\%D0\%BF\#T ext

[33] A. Cobham, P. Janský. Global distribution of revenue loss from corporate tax avoidance: re-estimation and country results. Journal of International Development, Vol.30 No. 2, 206-232, 2018.

[34] A. C. González Cabral, S. Appelt, T. Hanappi. Corporate Effective Tax Rates for R\&D: The Case of 
Expenditure-Based R\&D Tax Incentives. OECD, Paris, 2021.

[35] KPMG. Corporate Tax Rates for 2011 - 2021 by Country. 2021. Online available from

https://home.kpmg/xx/en/home/services/tax/tax-tools-and-re sources/tax-rates-online/corporate-tax-rates-table.html

[36] PricewaterhouseCoopers. Headline Rates for WWTS Territories. 2021. Online available from https://taxsummaries..com/quick-charts/corporate-income-ta $\mathrm{X}$-cit-rates\#anchor-U

[37] C. Azemar, R. Desbordes, I. Wooton. Is international tax competition only about taxes? A market-based perspective. Journal of Comparative Economics, Vol. 48, No. 4, 891-912, 2020.

[38] P. Janský, M. Palanský. Estimating the scale of profit shifting and tax revenue losses related to foreign direct investment. International Tax and Public Finance, Vol. 26, 1048-1103, 2019.

[39] M. Giofré. COVID-19 stringency measures and foreign investment: An early assessment. The North American Journal of Economics and Finance, Vol. 58, 101536, 2021.

[40] S, R. Baker, N. Bloom, S. J. Davis, S. J. Terry. COVID-Induced Economic Uncertainty. 2020. Online available from

https://www.nber.org/system/files/working papers/w26983/ w26983.pdf

[41] E. Forsythe, L. B. Kahn, F. Lange, D. G. Wiczer. Labor Demand in the Time of COVID-19: Evidence from Vacancy Postings and UI Claims. 2020. Online available from https://www.nber.org/system/files/working papers/w27061/ w27061.pdf

[42] United Nations Conference on Trade and Development. World Investment Report 2020: International Production Beyond the Pandemic. United Nations publication, Geneva, 2020.

[43] S. A. Bello, L. O. Oyedele, O. O. Akinade, M. Bilal, J. M. Davila Delgado, L. A. Akanbi, A. O. Ajayi, H. A. Owolabi. Cloud computing in construction industry: Use cases, benefits and challenges. Automation in Construction. Vol. 122, 103441, 2021. https://doi.org/10.1016/j.autcon.2020.103441

[44] L. E. Christiansen, A. Habib, M. MacDonald, D. Malacrino. Getting Back to Growth. 2021. Online available from https://blogs.imf.org/2021/06/10/getting-back-to-growth

[45] C. Corrado, J. Haskel, C. Jona-Lasinio, M. Iommi. Intangible investment in the EU and US before and since the Great Recession and its contribution to productivity growth. Journal of Infrastructure, Policy and Development, Vol. 2, No. 1, 11-36, 2018.

https://doi.org/10.24294/jipd.v2i1.205

[46] R. Döttling, L. Ratnovski. Monetary Policy and Intangible Investment. 2021. Online available from https://ssrn.com/abstract=3612304
[47] E. Hazan, S. Smit, J. Woetzel, B. Cvetanovski, M. Krishnan, B. Gregg, J. Perrey, K. Hjarta. Getting tangible about intangibles: The future of growth and productivity? McKinsey Global Institute. 2021. Online available from https://www.mckinsey.com/business-functions/marketing-a nd-sales/our-insights/getting-tangible-about-intangibles-thefuture-of-growth-and-productivity

[48] State Statistics Service of Ukraine. 2021. Online available from http://www.ukrstat.gov.ua/

[49] OECD. OECD Secretary-General Tax Report to G20 Finance Ministers and Central Bank Governors. 2021. Online available from www.oecd.org/tax/oecd-secretary-general-tax-report-g20-fi nance-ministers-october-2021.pdf

[50] OECD/G20 Base Erosion and Profit Shifting Project. Statement on a Two-Pillar Solution to Address the Tax Challenges Arising from the Digitalisation of the Economy. 2021. Online available from

https://www.oecd.org/tax/beps/statement-on-a-two-pillar-sol ution-to-address-the-tax-challenges-arising-from-the-digitali sation-of-the-economy-october-2021.pdf

[51] Elemes, B. Blaylock, C. Spence. Tax-motivated profit shifting in big 4 networks: Evidence from Europe. Accounting, Organizations and Society, Vol. 94, 101267, 2021. https://doi.org/10.1016/j.aos.2021.101267

[52] A, Cobham, P. Janský. Estimating Illicit Financial Flows: A Critical Guide to the Data, Methodologies, and Findings. Oxford Scholarship Online, Oxford, 2020.

[53] T. W. Tørsløv. The Missing Profits of Nations. 2018 Online available from https://www.nber.org/system/files/working papers/w24701/ w24701.pdf

[54]A. Bourgain, S. Zanaj. A tax competition approach to resource taxation in developing countries. Resources Policy, $65,101519,2020$.

[55] Organization for Economic Cooperation and Development. Transfer Pricing Guidance on Financial Transactions OECD, Paris, 2020

[56] M. L. Granda. Tax haven ownership and business groups: Tax avoidance incentives in Ecuadorian firms. Journal of Business Research, Vol. 130, 698-708, 2020.

[57] M. Mardan, M. Stimmelmayr. Tax competition between developed, emerging, and developing countries - Same same but different? Journal of Development Economics, Vol. 146, 102491, 2020.

[58] L. Wier. Tax-motivated transfer mispricing in South Africa: Direct evidence using transaction data. Journal of Public Economics, 184, 104153, 2020.

[59] L. F. Kemmanang, resource dependence cushion the impact of thin capitalization rules on foreign investment inflows? Evidence from Africa. Resources Policy, Vol. 72, 102055, 2021. 